\section{Pre-EMP-tive strike against GBM}

\section{By Michael J. Haas, Senior Writer}

University of California, Los Angeles researchers have treated glioblastoma in mice by inhibiting epithelial membrane protein $2 .{ }^{1}$ The findings open up a new indication for spinout Paganini Biopharma Inc., which has a mAb against the target in development for triplenegative breast cancer.

Epithelial membrane protein 2 (EMP2) is expressed in multiple tissues, including heart, lung, uterus and eye, in which it interacts with integrins to regulate adhesion between cells and the extracellular matrix. ${ }^{2,3}$

Over the past eight years, several UCLA teams led by Madhuri Wadehra showed that EMP2 was upregulated in endometrial, ovarian and breast cancers, in which it correlated with advanced disease and poor survival, ${ }^{4-7}$ and that inhibiting the protein reduced ovarian and breast tumor growth in mice. ${ }^{6,7}$

Based on a different group's gene expression research, ${ }^{8}$ Wadehra hypothesized that EMP2 also could be a target in glioblastoma multiforme (GBM) - the most common and aggressive form of brain cancer.

First, the team showed that EMP2 upregulation directly correlated with EMP2 levels in GBM. In a panel of samples from more than 300 patients with GBM, up to 95\% of primary GBM tumors had higher levels of EMP2 than the surrounding normal brain tissue.

In addition, tumor levels of EMP2 correlated positively with activation of Src-an intracellular tyrosine kinase that contributes to cancer progression-and correlated negatively with patient survival.

In human GBM cell lines, EMP2 enhanced cell invasiveness by activating the integrin $\alpha_{\mathrm{v}} \beta_{3}(\mathrm{CD} 51 / \mathrm{CD} 61)$-focal adhesion kinase (FAK)-Src signaling pathway. In mice injected intracranially with human GBM cell lines, imaging studies showed that tumors generated from $E M P 2^{+}$cells were more invasive than tumors produced from cells in which EMP2 had been silenced with shRNA.

Lastly, the team tested two EMP2 inhibitors in mice with subcutaneous GBM xenografts. The first was Paganini's PG-101 anti-EMP2 mAb. The second was an anti-EMP2 diabody, which is a type of antibody fragment that is formed from two single-chain variable fragments and potentially has higher affinity for its target than a mAb.

In the models, i.p. administration of either agent decreased tumor growth compared with administration of inactive controls.

Data were reported in The Journal of Biological Chemistry.

Wadehra is an adjunct assistant professor of pathology and laboratory medicine at the University of California, Los Angeles David Geffen School of Medicine. She also is a member of the Cancer and Stem Cell Biology Program Area at the University of California, Los Angeles Jonsson Comprehensive Cancer Center and a cofounder of Paganini.

The team included a researcher from the University of California, San Diego.

\section{Safe harbor upstream}

Wadehra told SciBX that EMP2 inhibitors could treat cancer with fewer side effects than inhibitors of the CD51/CD61-FAK-Src pathway. She said that the latter three targets are widely expressed by normal cells, whereas EMP2 is highly expressed in GBM and other tumors and has limited expression in normal tissue.

"We feel that targeting EMP2 may be a novel way to downregulate the CD51/CD61-FAK-Src pathway that has been shown to be important for tumorigenesis," she said.

At least 16 companies have cancer compounds that inhibit

Table 1. EMP2's downstream crowd. University of California, Los Angeles researchers have shown that in mouse models of glioblastoma multiforme (GBM) and breast cancer, epithelial membrane protein 2 (EMP2) activates the integrin $\alpha_{v} \beta_{3}$ (CD51/CD61)-focal adhesion kinase (FAK)Src signaling pathway that drives cancer progression. ${ }^{1}$ At least 16 companies have therapies on the market or in the clinic that target 1 of the 3 downstream components on that signaling pathway to treat cancer.

Source: BCIQ: BioCentury Online Intelligence

\begin{tabular}{|c|c|c|c|}
\hline Company & Product & Description & Status \\
\hline $\begin{array}{l}\text { Bristol-Myers Squibb Co. } \\
\text { (NYSE:BMY)/Otsuka Pharmaceutical } \\
\text { Co. Ltd. }\end{array}$ & $\begin{array}{l}\text { Sprycel dasatinib } \\
\text { (BMS-354825) }\end{array}$ & $\begin{array}{l}\text { Small molecule inhibitor of BCR-ABL } \\
\text { tyrosine kinase and Src kinase }\end{array}$ & $\begin{array}{l}\text { Marketed for acute lymphoblastic } \\
\text { leukemia (ALL) and chronic } \\
\text { myelogenous leukemia (CML); Phase II } \\
\text { for breast and pancreatic cancers; Phase } \\
\text { I for relapsed or refractory leukemia }\end{array}$ \\
\hline Pfizer Inc. (NYSE:PFE)/Avillion LLP & $\begin{array}{l}\text { Bosulif bosutinib } \\
\text { (PF-05208763; SKI-606) }\end{array}$ & Dual inhibitor of BCR-ABL and Src kinases & Marketed for CML \\
\hline Merck KGaA (Xetra:MRK) & Cilengitide (EMD 121974) & Inhibitor of CD51/CD61 and integrin $\alpha_{\mathrm{v}} \beta_{5}$ & $\begin{array}{l}\text { Phase III for brain cancer; Phase II for } \\
\text { head and neck cancer, non-small cell } \\
\text { lung cancer (NSCLC) and melanoma }\end{array}$ \\
\hline $\begin{array}{l}\text { Bristol-Myers Squibb/Johnson \& } \\
\text { Johnson (NYSE:JNJ) }\end{array}$ & $\begin{array}{l}\text { Intetumumab (BGB-101; } \\
\text { CNTO-95) }\end{array}$ & $\begin{array}{l}\text { Human } m A b \text { targeting CD51/CD61, } \\
\text { integrin } \alpha_{v} \beta_{5} \text {, integrin } \alpha_{v} \beta_{6} \text { and integrin } \\
\alpha_{v} \beta_{1}(\mathrm{CD} 51 / \mathrm{CD} 29)\end{array}$ & $\begin{array}{l}\text { Phase II for melanoma and castration- } \\
\text { resistant prostate cancer (CRPC); Phase } \\
\text { I for solid tumors }\end{array}$ \\
\hline
\end{tabular}

(Continues on p. 2) 
Table 1. EMP2's downstream crowd.

\begin{tabular}{|c|c|c|c|}
\hline Company & Product & Description & Status \\
\hline $\begin{array}{l}\text { Kinex Pharmaceuticals LLC/Hanmi } \\
\text { Pharmaceutical Co. Ltd. } \\
\text { (KOSDAQ:128940) }\end{array}$ & KX01 (KX2-391) & Small molecule, non-ATP Src inhibitor & $\begin{array}{l}\text { Phase II for prostate cancer; Phase } \\
\text { I/II for breast cancer, gastric cancer } \\
\text { and solid tumors; Phase Ib for acute } \\
\text { myelogenous leukemia (AML) }\end{array}$ \\
\hline Pfizer/Verastem Inc. (NASDAQ:VSTM) & $\begin{array}{l}\text { Defactinib (VS-6063; } \\
\text { formerly PF-4554878) }\end{array}$ & Inhibitor of FAK targeting cancer stem cells & $\begin{array}{l}\text { Phase II for mesothelioma and NSCLC; } \\
\text { Phase I for ovarian cancer and solid } \\
\text { tumors }\end{array}$ \\
\hline Tactic Pharma LLC & ATN-161 & Inhibitor of CD51/CD61 and integrin $\alpha_{5} \beta_{1}$ & $\begin{array}{l}\text { Phase II for brain cancer; Phase I for } \\
\text { head and neck cancer }\end{array}$ \\
\hline BioAlliance Pharma S.A. (Euronext:BIO) & AMEP (BA-015) & $\begin{array}{l}\text { Plasmid encoding a peptide targeting } \\
\text { CD51/CD61 and integrin } \alpha_{5} \beta_{1}\end{array}$ & Phase I/II for melanoma \\
\hline Nippon Shinyaku Co. Ltd. (Tokyo:4516) & NS-018 & Inhibitor of Src and Janus kinase-2 (JAK-2) & Phase I/II for hematologic malignancies \\
\hline Verastem & VS-4718 & Inhibitor of FAK targeting cancer stem cells & Phase I for solid tumors \\
\hline AstraZeneca plc (LSE:AZN; NYSE:AZN) & AZD0424 & Src inhibitor & Phase I for advanced solid tumors \\
\hline $\begin{array}{l}\text { GlaxoSmithKline plc (LSE:GSK; } \\
\text { NYSE:GSK) }\end{array}$ & GSK2256098 & Small molecule FAK inhibitor & Phase I for solid tumors \\
\hline $\begin{array}{l}\text { Teva Pharmaceutical Industries Ltd. } \\
\text { (NYSE:TEVA) }\end{array}$ & CEP-37440 & $\begin{array}{l}\text { Inhibitor of FAK and anaplastic lymphoma } \\
\text { kinase (ALK) }\end{array}$ & Phase I for solid tumors \\
\hline ValiRx plc (LSE:VAL) & VAL201 & Src inhibitor & Phase I for CRPC and other cancers \\
\hline
\end{tabular}

CD51/CD61, FAK or Src on the market or in clinical development (see Table 1, "EMP2's downstream crowd").

Before Paganini decides whether to develop PG-101 or the diabody to treat GBM, Wadehra said that the UCLA team needs to compare the efficacy and delivery routes of each agent in mice with orthotopic, intracranial GBM tumors.

Initially the team will test the effect of direct intracranial administration of the antibody in the orthotopic models. "But we are also going to test various delivery strategies-including stem cell-based delivery-to determine whether we can get the diabody across the blood brain barrier," she said.

UCLA owns a patent portfolio that covers several anti-EMP2 mAbs, their uses to treat cancer and ophthalmic indications, and diagnostic uses of EMP2, Wadehra said. The IP portfolio is licensed to Paganini, which spun out of UCLA in 2011.

Paganini president Gary Lazar said that the biotech is in discussions with potential partners for the clinical development of PG-101 to treat triplenegative breast cancer.

Wadehra said that the team has not found a maximum tolerated dose of PG-101. "We have shown that the antibody administered at $40 \mathrm{mg} / \mathrm{kg}$ doses twice a week is safe and has no measurable toxicity," she said.

Lazar added that the anti-EMP2 diabody is not yet in Paganini's pipeline because it was developed as a research compound and has a short serum half-life.

"Additional academic studies are needed to determine its efficacy" in treating GBM or as an intravitreally administered agent to treat the ophthalmic diseases Paganini is pursuing, such as those involving aberrant proliferation of retinal pigment epithelial cells or aberrant corneal neovascularization, he said.

Haas, M.J. SciBX 7(14); doi:10.1038/scibx.2014.389

Published online April 10, 2014

\section{REFERENCES}

1. Qin, Y. et al. J. Biol. Chem.; published online March 18, 2014; doi:10.1074/jbc.M113.543728

Contact: Madhuri Wadehra, University of California, Los Angeles David Geffen School of Medicine, Los Angeles, Calif. e-mail:mwadehra@mednet.ucla.edu

2. Wadehra, M. et al. J. Biol. Chem. 277, 41094-41100 (2002)

3. Wadehra, M. et al. Exp. Mol. Pathol. 74, 106-112 (2003)

4. Wadehra, M. et al. Cancer 107, 90-98 (2006)

5. Habeeb, O. et al. Cancer 116, 4718-4726 (2010)

6. Fu, M. et al. Clin. Cancer Res. 16, 3954-3963 (2010)

7. Fu, M. et al. Mol. Cancer Ther.; published online Jan. 21, 2014; doi:10.1158/1535-7163.MCT-13-0199

8. Freije, W.A. et al. Cancer Res. 64, 6503-6510 (2004)

COMPANIES AND INSTITUTIONS MENTIONED

Paganini Biopharma Inc., Encino, Calif. University of California, Los Angeles, Calif. University of California, Los Angeles, David Geffen School of Medicine, Los Angeles, Calif. University of California, Los Angeles, Jonsson Comprehensive Cancer Center, Los Angeles, Calif. University of California, San Diego, La Jolla, Calif. 